なってきた。しかし，その作用機序は不明な点が多く，インプラントの表面性状が骨芽細胞の接着関連分子におよぼ す影響について検討した報告は少ない，細胞は，focal adhesionまたはclose contact と呼ばれる構造によって， インプラントのような人エマトリックスに接着し，フィブロネクチン，インテグリン，テーリン，ビンキュリン，ア クチンなどの多くの分子が関与しているといわれている．今回，インプラントの表面性状の違いが細胞接着におよぼ す影響を検討する目的で, チタン板上でヒト骨肉腫細胞 MG63を培養し, チタン板表面の性状や培養条件を变化さ せたときの focal adhesionの形成を接着関連分子の免疫染色によって観察した．さらに，細胞接着の制御と関連し ているリン酸化チロシンの局在についてあ観察を行ったので報告する.

\title{
The formation of focal adhesion on titanium
}

Hirofumi Kido, Keiko Nakamura ${ }^{2}$, Rie Hirado ${ }^{2}$, Masao Morikawa ${ }^{2}$, Nobuaki Nakamuta ${ }^{3}$ and Tatsuji Haneji ${ }^{3}$ ( ${ }^{1}$ Department of Oral Implantology, Fukuoka Dental College, ${ }^{2}$ First Department of Prosthetic Dentistry and ${ }^{3}$ First Department of Oral Anatomy, Kyushu Dental College)

A human osteoblastic cell line (MG 63) was incubated on titanium plates and cover glasses with $10 \%$ serum and without serum. The localization of fibronectin, vinculin, actin and phosphotyrosine was examined by immunofluorescent technique to observe the formation of focal adhesion. The formation of focal adhesion of the osteoblasts that were incubated with $10 \%$ serum was observed on both titanium plates and cover glasses. The spreading and the formation of focal adhesion of osteoblasts on cover glasses without serum were not observed, while on titanium plates, the spreading and the formation of focal adhesion were confirmed. Therefore it was suggested that the titanium may promote the formation of focal adhesion.

\section{9. 骨芽細胞に発現するアビジン結合蛋白}

○平戸 理惠'·守川 雅男'·小林熬'羽地 達次 ${ }^{2}$

${ }^{1}$ 九雬大·補経 $1,{ }^{2}$ 九歯大·口解 1

アビジンービオチン複合体法 (ABC 法) は細胞生物学, 生化学, 分子生物学等の分野に広く応用されている. 我々 はこの方法を応用することにより, 肝臓, 㴿下腺, 卵細胞等に存在する内在性アビジン結合蛋白をより簡易な方法で 検出することを報告してきた，今回，我々は骨芽細胞の性質を有するヒト骨肉腫細胞（Saos-2, MG63）及びマウス 骨芽細胞 MC3T3-E1 に発現するアビジン結合蛋白をトランスブロッティング法および細胞化学的方法で検討した. 通法に従い培養した細胞から経時的に蛋白溶液を調整し, SDS-ポリアクリルアミド電気泳動を行い, 蛋白を分離し た.ゲル内の蛋白をPVDF 膜に転写した後アビジンーパーオキシダーゼと反応させ，アビジン結合蛋白を検出した. また, 固定した培養細胞をアビジン-FITCで反応させ, 蛍光顕微鏡で観察した。その結果全ての細胞において $120 \mathrm{kDa} ， 74 \mathrm{kDa} ， 72 \mathrm{kDa}$ のバンドが検出された. アビジン-FITC は細胞質に存在する蛋白を認識した. さらに他 の細胞 (SCC25, HSG, CHO, 3T3-L1, HeLa) についても同様の結果を得た.

Identification of avidin-interacting proteins in osteoblastic cells

Rie Hirado ${ }^{1}$, Masao Morikawa ${ }^{1}$, Shigeru Kobayashi ${ }^{2}$ and Tatsuji Haneji ${ }^{2}$ ( ${ }^{1}$ First Department of Prosthetic Dentistry and ${ }^{2}$ First Department of Oral Anatomy, Kyushu Dental College)

Avidin-biotin complex has been widely used in immunohistochemical and biochemical studies. However, non-specific interactions of avidin with certain tissues have been observed. One of the reasons for these non-specific reaction is presence of avidin-interaction proteins in the cells. Avidininteracting proteins were reported not to detect in higher eukaryotes because these proteins are high in molecular weight and low in abundance. In the present study, peroxidase-avidin and avidin-FITC were used to detect avidin-binding proteins in cultured osteoblastic cells. After SDS-PAGE, proteins were transferred to the transfer membranes. Blocked membranes were incubated with avidinperoxidase. Bound peroxidase was detected by developing the membranes with 4-chloro-1-naphtol and hydrogen peroxide. Cultured cells also were incubated with avidin-FITC and observed under a 
microscope. Avidin-peroxidase interacted with three bands with estimated molecular weights of 72, 74, and $120 \mathrm{kDa}$ present in the cultured osteoblastic cells (MC3T3-E1 cells, MG63 cells, and Saos-2 cells). These proteins were also detected in all the cells examined (CHO, HeLa, HSG, SCC-25). Avidininteracting proteins were localized in mitochondria of MC3 T3-E 1 cells determined by FITC-avidin. The present results indicate that avidin-interacting proteins in the cultured cells are detected with avidin, suggesting that non-specific interactions may occur in cultured cells with $A B C$ method.

\section{0. 動摇を伴う外鹪性咬合歯のプレスケールによる診查法}

\section{○瀬尾 隆文·内藤 徹·日高 理智·横田 誠}

九歯大·保存 2

外傷性咬合は蒾周疾患の増悪因子の一つとされており，それを除去するための咬合調整は蒾周治療の重要な要素の 一つとされている. しかし，外傷性咬合が存在すると思われる歯は，歯の動摇や歯の接触を回避する顎運動のために 咬合力が介在している可能性は低く，咬合紙やワックスを応用した従来の診査や，プレスケールの通法による診査で は外傷性咬合が介在している歯を検出できない恐れがある，今回我々は動摇歯を隣在歯と固定し，固定しない場合と の咬合力，咬合面積との差を検討することより外傷性咬合歯の検出を行うことを考案し，この方法を用いて咬合性外 傷の疑われる患者に応用した。その結果，従来のプレスケールの採取法では検出出来なかった外傷性咬合と思われる 接触状態が確認できた。一般に外傷性咬合というと，あたかもその菌に「強い外力」が加わっているように受け止め られやすいが, 大きな咬合力が加わる前にその歯が位置を変えてしまっている可能性があることがわかった.

\section{Application of Dental Prescale ${ }^{\circledR}$ for the examination of occlusal trauma with mobile tooth}

Takafumi Seo, Toru Naito, Masatoshi Hitaka and Makoto Yokota (Department of Periodontology and Endodontology, Kyushu Dental College)

Occlusal adjustment is an important technique in periodontal therapy. Conventional examination technique, such as occluding paper or indicator wax may lead the examiner to overlook the occlusal contact due to the excessive tooth mobility. Also, it is impossible to measure the amount of occlusal pressure which is affecting the tooth. Dental Prescale ${ }^{\circledR}$ has the potential to compensate these limitations. Under the new sampling procedure, sampling was taken at intercuspal position and at intercuspal position with splinting the mobile tooth with self-cure resin. In this sampling technique, higher occlusal pressure was observed on the mobile tooth than in conventional sampling. This finding can be imagined that the mobile teeth displace away from tight tooth contact surface during intercuspal position. These results suggested that Dental Prescale ${ }^{\circledR}$ sampling in conjunction with the tooth splint might be useful for the detection of occlusal contacts in teeth suspected of trauma from occlusion.

\section{1. 支台歯の挙動解析装置の開発}

○岩切 幸·今村 義治·城戸 寛史·今浪 秀樹·松木 貴彦·三宅 茂樹·守川 雅男 九歯大·補綴 1

パーシャルデンチャーにおける大きな命題の一つである支台歯の挙動を今後, 生体上で解明していくに先立って, 当教室の今村が開発したレーザー光による解析装置ならびにシミュレーションモデル上でのこれまでの実験結果につ いて再検討した.

Kennedy II 級の症例に, 臨床で最も高頻度に使用されているェーカースクラスプ, フレキシブルサポートの代表 クロールの RPI 維持装置およびリジットサポートとしてクラトビルのI バークラスプの三種類のクラスプを使用し た片側性遊離端義蒾を製作し，第 1 人工大臼歯上に $1 \mathrm{~mm} / \mathrm{sec}$ の等速荷重を加えた際の支台霜の動きを上記装置で 計測し解析した. その結果，エーカースクラスプにおける従来考えられていた以上の過度な動きやこれまでの概念と は異なった RPI 維持装置の動きなど，興味ある幾つかの知見が得られた。 